\author{
D.S. Krylov, O.I. Kholod
}

\title{
THE EFFICIENCY OF THE ACTIVE CONTROLLED RECTIFIER OPERATION IN THE MAINS VOLTAGE DISTORTION MODE
}

\begin{abstract}
Goal. Checking the efficiency of the active rectifier with differences types of control systems in conditions of deep voltage distortions of a three-phase three-wire supply network. Methodology. The authors have used the Matlab/Simulink software environment to create a model of an active rectifier with various types of control systems as part of a frequency electric drive. We performed a series of simulations of the operating modes of an active rectifier with various control systems when the supply voltage is distorted. Results. When the active rectifier is operating in an unregulated mode, the distortions of the current and mains voltage exceed the maximum permissible values. The quality indicators of the mains current and mains voltage are significantly higher than the normally permissible values. In the absence of voltage distortions in the supply network, the operation of the active rectifier can effectively eliminate the distortions of the mains current, regardless of the type of control system of the active rectifier. In conditions of deep distortions of the supply network voltage, the operation of an active rectifier with a vector control system is more efficient than with a parametric control system. Originality. Criteria for determining the quality of consumed electricity at the connection point of the circuit are proposed. Practical significance. Recommendations have been developed for the use of active rectifier control systems when working with a distorted power supply voltage. References 8 , tables 4 , figures 11 .

Key words: active rectifier, vector control system, parametric control system, PWM frequency, mains voltage distortion, mains current distortion, total harmonic distortion.
\end{abstract}

Розглянуто роботу активного керованого випрямляча-джерела напруги (АВДН) з параметричною та векторною системами управління, які праџюють з фіксованою частотою модулячії в складі електроприводу потужністю 315 кВт паралельно з іншими навантаженнями в умовах спотворення напруги джерела живлення. Виконано математичне моделювання АВДН з різними системами управління. Запропоновано критерії визначення якості споживаної електроенергії в точиі підключення схеми. Розроблено рекомендачії щэодо використання систем управління АВДН при роботі зі спотвореною напругою джерела живлення. Бібл. 8, табл. 4, рис. 11.

Ключові слова: активний випрямляч, векторна система управління, параметрична система управління, частота ШІМ, спотворення напруги мережі, спотворення струму мережі, сумарний коефіцієнт гармонійних спотворень.

Рассмотрена работа активного управляемого выпрямителя-источника напряжения (АВИН) с параметрической и векторной системами управления, работающих с фиксированной частотой модуляции в составе электропривода мощностью $315 \kappa B m$ параллельно с другими нагрузками в условиях искажённого напряжения источника питания. Выполнено математическое моделирование АВИН с различными системами управления. Предложены критерии определения качества потребляемой электроэнергии в точке подключения схемы. Разработаны рекомендации по использованию систем управления АВИН при работе с искажённым напряжением источника питания. Библ. 8, табл. 4, рис. 11.

Ключевые слова: активный выпрямитель, векторная система управления, параметрическая система управления, частота ШИМ, искажения напряжения сети, искажения сетевого тока, суммарный коэффициент гармонических искажений.

Introduction. Voltage-sources active rectifiers (VSARs) are increasingly used in the input circuits of medium-power industrial drives based on autonomous voltage inverters, providing a two-way exchange of energy between the motor and the mains with an almost sinusoidal current at the input of the circuit with a zero phase shift relative to the phase voltage [1-3]. The efficiency of the VSAR circuit is ensured, first of all, by the correct choice of the structure of its control system $[4,5]$. In [6], the authors analyzed the efficiency of the basic circuits of control systems (CS) of the VSAR when they implement the main functions assigned to the power circuit of the converter, and also proposed a new structure of the CS based on the theory of representing instantaneous currents and voltages of a three-phase network in the form of generalized vectors in $p-q-r$ coordinates. The complication of the CS of the VSAR is justified when using the converter in an industrial workshop, where several loads can be powered from a common source, which mutually influence each other, i.e. in conditions where long-term distortion is possible in the supply voltage.
The goal of the work is to test the efficiency of the VSAR operation with various types of control systems in conditions of deep voltage distortions of a three-phase three-wire mains supply.

The structure of the drive power supply circuit. The block diagram of the investigated frequency electric drive of medium power using a three-phase voltagesources active rectifiers is shown in Fig. 1.

It contains: a source of three-phase $\mathrm{AC}$ voltage $u_{S}$; converter transformer $\mathrm{T}$; input reactors of the VSAR, which, if necessary, can be combined with a high pass filter HPF; an active rectifier AR, made in bridge circuit on alternating current switches; two capacitors $C_{1}$ and $C_{2}$ of the same capacitance connected in the intermediate DC circuit; a three-phase bridge autonomous voltage inverter VI, also made according to a bridge circuit on alternating current keys and loaded on a three-phase induction machine (load) L. The converter transformer $\mathrm{T}$, in the general case, can also supply other loads OL connected to the terminals of its valve windings in parallel to the circuit under study. 


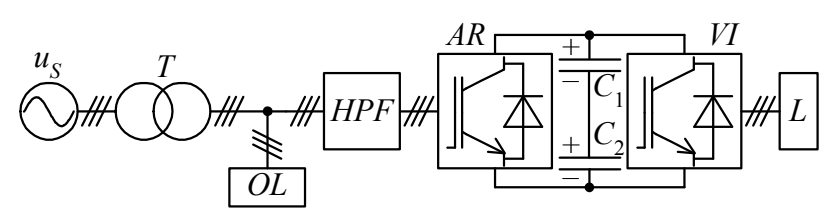

Fig. 1. Block diagram of a frequency electric drive with VSAR

In practice, this circuit should also contain switching and protective devices, as well as the output filter of the voltage inverter. They are not shown in Fig. 1, since they do not have a significant effect on the operation of the VSAR and are not the subject of this paper.

For the correct perception of the results obtained in the framework of studies consistently carried out by the authors, the parameters of the main elements of the system under consideration were taken the same as in [6].

The prototype of the load was an $\mathrm{ABB}$ induction motor type M3BP 355 SMC4, whose passport data are given in Table 1.

Table 1

Load parameters

\begin{tabular}{|c|c|}
\hline Parameter & Value \\
\hline Stator line voltage, $\mathrm{V}$ & 400 \\
\hline Rated frequency, $\mathrm{Hz}$ & 50 \\
\hline Rated power, $\mathrm{kW}$ & 315 \\
\hline Rated stator current, $\mathrm{A}$ & 553 \\
\hline
\end{tabular}

Since the study of the dynamics of the operation of an induction electric drive is not the purpose of this paper, and most VSAR control systems easily cope with the task of recuperation, the load model is represented by an equivalent $R L$ circuit that provides the same power at the load.

The CS of the VI is built on the principle of sinusoidal pulse-width modulation with a frequency and depth of regulation fixed at $4 \mathrm{kHz}$, set by a closed-loop automatic control system with feedback on the input power of the inverter, maintained in any mode at the level of the rated active power of the motor, i.e. $315 \mathrm{~kW}$. The frequency of operation of the VSAR switch in all modes is also adopted equal to $4 \mathrm{kHz}$.

The total capacitance of the DC link is selected equal to $28 \mathrm{mF}$ from the condition of ensuring the required level of ripple of the rectified voltage, both in uncontrolled and in the active mode of AR operation. The value of the input inductance of the VSAr phase is taken equal to $150 \mu \mathrm{H}$, which, in combination with the present inductance of the supply mains, ensures stable operation of the circuit in all modes.

The short-circuit power of the supply mains at the connection point of the converter is $150 \mathrm{MVA}$.

The converter transformer with installed power of 1 MVA ensures the conversion of the line voltage of the supply mains at the level of $6 \mathrm{kV}$ into line voltage $0.4 \mathrm{kV}$ with the possibility of parallel connection of two more similar converters or another load of the corresponding power.

Quality assessment criteria. When assessing the quality of consumed electricity and the level of influence of the converter on the supply mains, it is necessary to set the main criteria by which we will assess the degree of success in the application of a particular technical solution.

According to $[7,8]$, it is possible to accurately determine the degree of mutual influence of the converter and the supply mains by calculating the total harmonic distortion THD of the voltage and current of the supply mains, as well as the voltage unbalance factor for the reverse and zero sequence at the converter connection point to the mains.

The total harmonic distortion is defined $[7,8]$ as the ratio of the root-mean-square sum of the higher harmonics of the signal to its first harmonic and is usually taken as a percentage. For phase current and mains voltage, it is defined as

$$
T H D_{I}=\frac{\sqrt{\sum_{k=2}^{\infty} I_{k}^{2}}}{I_{1}} 100 \%,
$$

$$
T H D_{U}=\frac{\sqrt{\sum_{k=2}^{\infty} U_{k}^{2}}}{U_{1}} 100 \%,
$$

where $I_{k}$ and $U_{k}$ are the effective values of the $k$-th harmonic of the phase current and voltage at the point where the converter is connected to the network; $I_{1}$ and $U_{1}$ are the effective values of the 1 st harmonic of the phase current and voltage at the connection point.

The voltage unbalance factor in the reverse sequence can be determined from the expression [7]

$$
K_{N S 2}=\frac{U_{2(1)}}{U_{1(1)}} 100 \%,
$$

where $U_{1(1)}$ and $U_{2(1)}$ are the effective voltage values, respectively, of the positive and negative sequence of the fundamental frequency of the three-phase voltage system, which can be defined as [7]

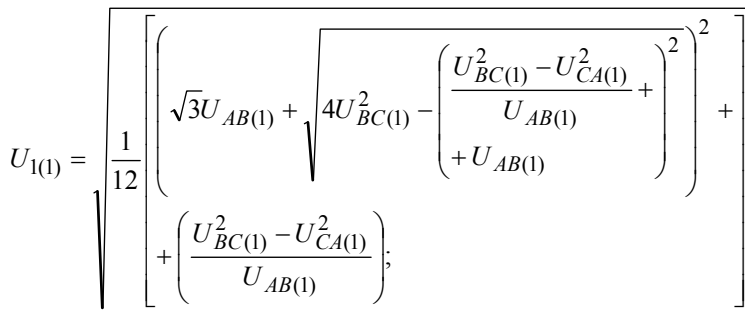

$$
U_{2(1)}=\sqrt{\frac{1}{12}\left[\begin{array}{l}
\left.\sqrt{3} U_{A B(1)}-\sqrt{4 U_{B C(1)}^{2}-\left(\frac{U_{B C(1)}^{2}-U_{C A(1)}^{2}}{U_{A B(1)}}+\right)^{2}}\right)^{2}+ \\
+\left(\frac{U_{A B(1)}^{2}}{\left.U_{C(1)}-U_{C A(1)}^{2}\right)}\right),
\end{array}\right]}
$$

where $U_{A B(1)}, U_{B C(1)}, U_{C A(1)}$ are the effective values of the first harmonics of the line voltages of the supply mains at the converter connection point.

Zero-sequence voltage unbalance factor [7] in the circuit of Fig. 1 is not determined due to the absence of a neutral wire in it. 
The structure of the VSAR control system. In [6], the authors showed that among the tracking structures of the CS of the VSAR with a fixed modulation frequency, it is advisable to use the voltage-controlled circuit shown in Fig. 2.

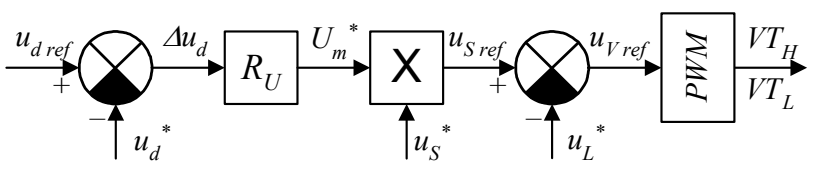

Fig. 2. Block diagram of the CS with voltage control

Its principle of operation is based on the generation of the reference signal of the PWM generator in the form of a voltage difference proportional to the voltage of the mains phase, and a voltage drop across the converter input choke. This allows to eliminate the uncertainty in setting the phase of the current of the supply mains, which arises when fixing the modulation frequency of the circuit, and to maintain its zero value in all operating modes of the circuit [6]. The disadvantage of the structure shown in Fig. 2 is the dependence of the reference signal of the PWM generator on the shape and phase of the supply voltage. This is unacceptable in the mode of deep distortion of the mains voltage and can lead to a significant decrease in the efficiency of VSAR operation.

To combat this, in [6], a structure was proposed that forms a signal for setting the PWM generator which is obtained as a result of representing the mains voltage and current in the form of spatial vectors in a rotating $p-q-r$ coordinate system and extracting components proportional to direct sequences of a three-phase system from their projections. This made it possible to create the structure of the VSAR control system, shown in Fig. 3, insensitive to distortion of the power supply voltage.

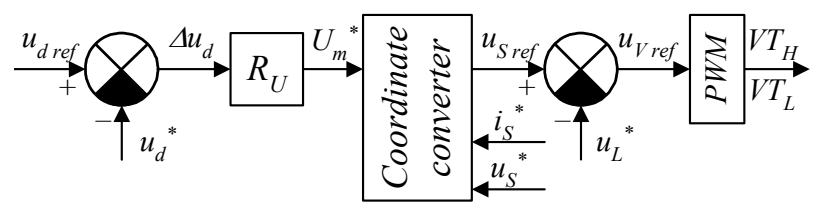

Fig. 3. Block diagram of the CS with vector control

Modelling the operation of the circuit. Modelling the operation of an active rectifier with two structures of control systems is carried out in the Matlab/Simulink software package in relation to a single power circuit corresponding to Fig. 1. The view of the Matlab model of the power circuit of the converter is shown in Fig. 4. It contains the following blocks:

- power circuit - blocks 1, 2, 5, 6, 10-12, 15, 16, 19;

- control systems - blocks 4, 13, 17;

- current and voltage sensors - blocks 3, 7-9, 14;

- parameter calculators - blocks 25, 27, 29;

- information output - blocks 20-24, 26, 28, 30.

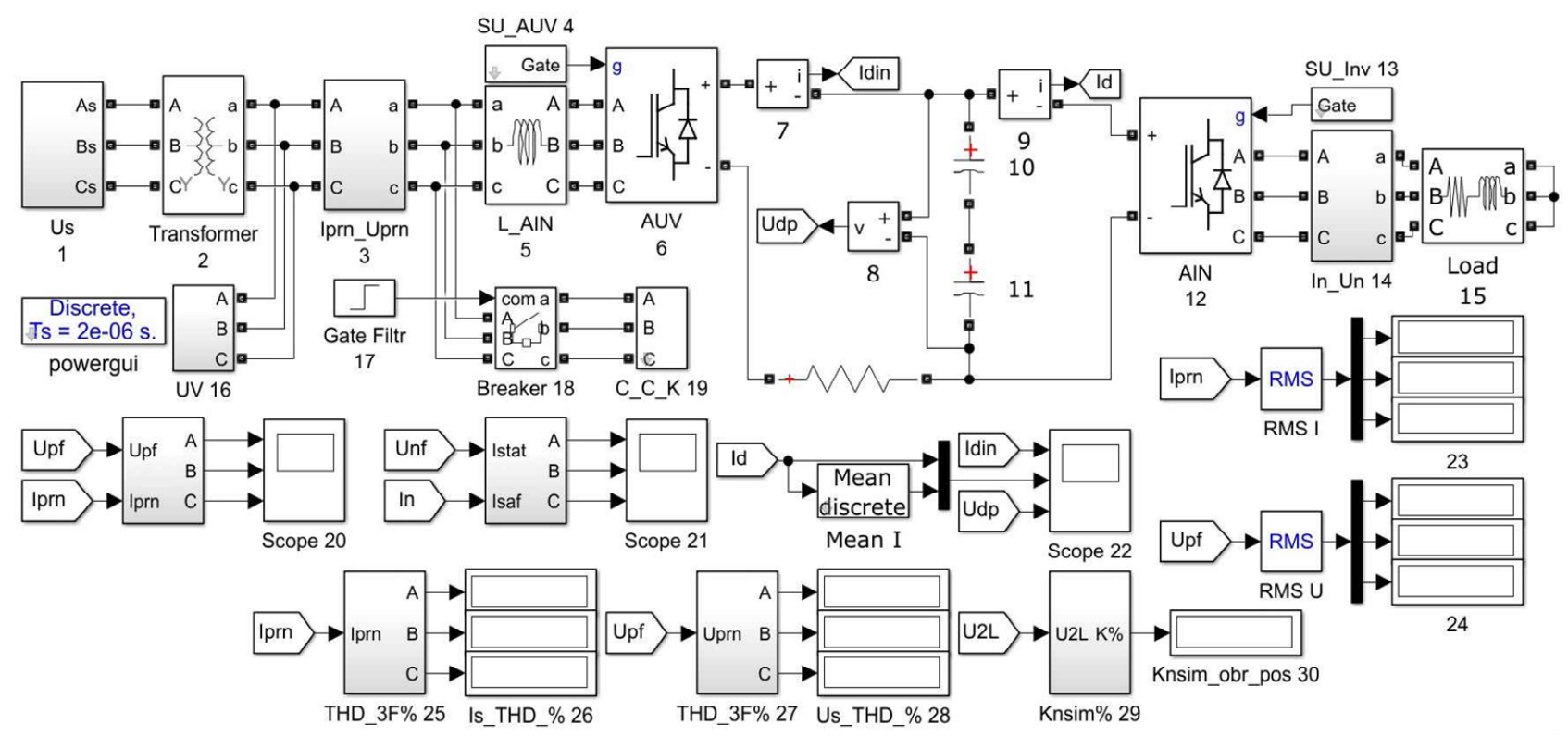

Fig. 4. Matlab model of VSAR power circuit

Purpose of the main blocks of the power circuit: 1 - three-phase AC voltage network; 2 - power transformer; 5 - input reactors of the VSAR; 6 - VSAR bridge; 10, 11 - capacitances of the DC link; 12 - VI bridge; 15 - load; 16 - additional load; 19 - high pass filter.

The parameters of the power circuits of the model are set in strict accordance with the data of the power circuit of the electric drive (Fig. 1), given above. An additional load of the circuit (16) is a six-pulse bridge controlled rectifier with installed power of $300 \mathrm{~kW}$, operating with control angle of 60 electrical degrees. It introduces switching distortions into the voltage of the valve winding of the converter transformer. The high pass filter (19) is designed to combat distortions in the supply voltage at the frequency of VSAR operation. It can be connected to the circuit through the switch (18) at the time specified by block 17. Parameter calculation blocks $(25,27,29)$ allow calculating the voltage unbalance factor in negative sequence, harmonic distortions of current and voltage of each phase of the valve winding of the converter transformer and display this data as a percentage (blocks 26, 28, 30). Blocks 23 and 24 display the effective values of the current and voltage of each 
phase of the valve winding of the transformer to assess their possible unbalance. Oscilloscope blocks (20-22) allow to visually evaluate the instantaneous values of the circuit parameters.

Simulation is carried out for three variants of VSAR control systems operation (block 4): unregulated mode transistor control pulses are not generated and VSAR operates in the mode of a diode rectifier; mode of operation with a parametric CS according to the structure of Fig. 2; mode of operation with a vector CS according to the structure of Fig. 3.

The following were taken as long-term distorting factors: switching distortions introduced by an additional load during its parallel operation with the main converter; decrease in the supply voltage of phase $B$ by $10 \%$ of the nominal value; phase $C$ voltage shift by 130 electrical degrees with respect to phase $B$ voltage. All measurements are taken with the high pass filter on.

Figure 5 shows the timing diagrams of the mains voltage and current for an unregulated operating mode (VSAR operates as a diode rectifier) in the absence of additional distortions introduced into the mains voltage as a result of external factors. It can be seen from the diagrams that the shape of the mains current differs significantly from the sinusoid, and its total harmonic distortion $\left(T H D_{I}\right)$ is several times higher than the maximum acceptable values, which is confirmed by the data, given in Table 2 .

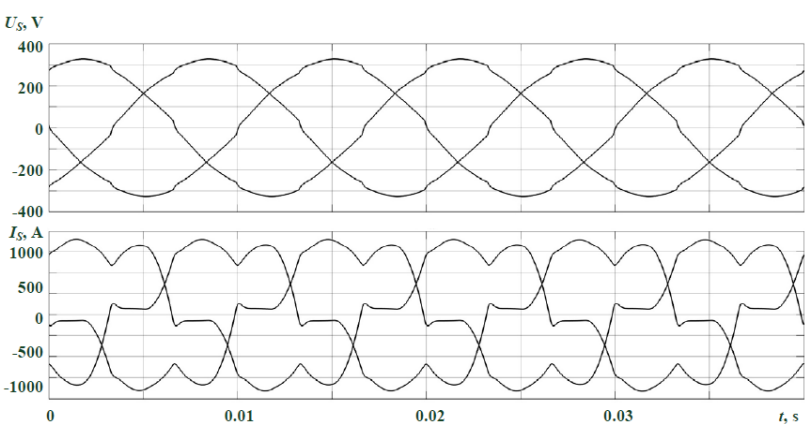

Fig. 5. Mains voltage and current in unregulated mode without distortion of mains parameters

Table 2

Mains parameters for three options of VSAR control systems operation in the absence of external network distortions

\begin{tabular}{|c|c|c|c|c|c|c|c|c|c|}
\hline $\begin{array}{l}\text { Circuit } \\
\text { type }\end{array}$ & \multicolumn{3}{|c|}{ Diode rectifier } & \multicolumn{3}{|c|}{$\begin{array}{c}\text { Parametric VSAR } \\
\text { CS }\end{array}$} & \multicolumn{3}{|c|}{$\begin{array}{c}\text { Vector VSAR } \\
\text { CS }\end{array}$} \\
\hline parameter & A & B & $\mathrm{C}$ & A & B & $\mathrm{C}$ & A & B & $\mathrm{C}$ \\
\hline$I_{2}$ & 499,8 & 499,0 & 499,9 & 468 & 468,1 & 468,3 & 467,7 & 467,8 & 468,2 \\
\hline$U_{2}$ & 228,2 & 228,2 & 228,2 & 229,4 & 229,4 & 229,4 & 229,4 & 229,4 & 229,4 \\
\hline$T H D_{I}$ & 25,23 & 25,37 & 25,36 & 2,88 & 2,86 & 2,88 & 2,88 & 2,85 & 2,86 \\
\hline$T H D_{U}$ & 2,99 & 2,99 & 2,99 & 4,44 & 4,43 & 4,44 & 4,43 & 4,42 & 4,43 \\
\hline$K_{N S 2}$ & \multicolumn{3}{|c|}{0,002} & \multicolumn{3}{|c|}{0,0007} & \multicolumn{3}{|c|}{0,0007} \\
\hline
\end{tabular}

Table 2 also shows that, regardless of the type of the CS, the VSAR allows to effectively eliminate the unwanted generation of higher harmonics of the current into the network and obtain the normally permissible values of $T H D_{I}$ and $T H D_{U}$.

Analyzing the data from the Table 2, we can talk about the same efficiency of the parametric and vector control systems of the VSAR in the symmetric undistorted network mode. Timing diagrams of the mains voltage and current for this case, shown in Fig. 6 are identical for both types of the CS.

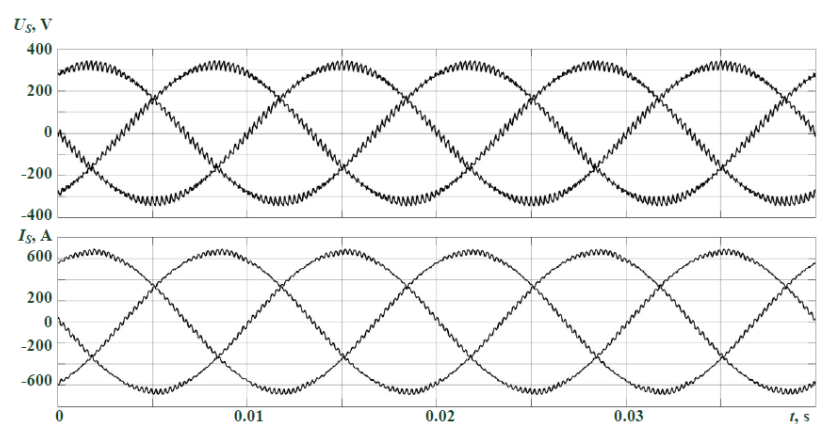

Fig. 6. Mains voltage and current with VSAR in the mode of symmetrical undistorted power supply

The introduction of symmetrical switching distortions from an additional load operating in parallel with the main converter significantly aggravates the picture of the circuit's operation in an unregulated mode and, according to Table 3 provide minor advantages to the vector control system. Timing diagrams of the operation of the circuit in an unregulated mode are shown in Fig. 7. Figure 8 shows diagrams illustrating the operation of the VSAR in the symmetric distortion mode, characteristic of both control systems.

Table 3

Mains parameters for three options of VSAR control system

operation in conditions of external symmetric distortions

\begin{tabular}{|c|c|c|c|c|c|c|c|c|c|}
\hline $\begin{array}{l}\text { Circuit } \\
\text { type }\end{array}$ & \multicolumn{3}{|c|}{ Diode rectifier } & \multicolumn{3}{|c|}{$\begin{array}{c}\text { Parametric VSAR } \\
\text { CS }\end{array}$} & \multicolumn{3}{|c|}{$\begin{array}{l}\text { Vector VSAR } \\
\text { CS }\end{array}$} \\
\hline parameter & A & B & $\mathrm{C}$ & A & B & $\mathrm{C}$ & A & B & $\mathrm{C}$ \\
\hline$I_{2}$ & 548,0 & 547,8 & 549,1 & 496,9 & 496,3 & 496,0 & 496,6 & 495,7 & 496,0 \\
\hline$U_{2}$ & 215,3 & 215,3 & 215,3 & 217,6 & 217,6 & 217,6 & 217,7 & 217,7 & 217,7 \\
\hline$T H D_{I}$ & 29,75 & 30,33 & 30,13 & 4,95 & 4,99 & 5,04 & 4,75 & 4,79 & 4,73 \\
\hline$T H D_{U}$ & 7,45 & 7,43 & 7,46 & 9,36 & 9,39 & 9,42 & 9,44 & 9,47 & 9,45 \\
\hline$K_{N S 2}$ & \multicolumn{3}{|c|}{0,004} & \multicolumn{3}{|c|}{0,0006} & \multicolumn{3}{|c|}{0,0005} \\
\hline
\end{tabular}

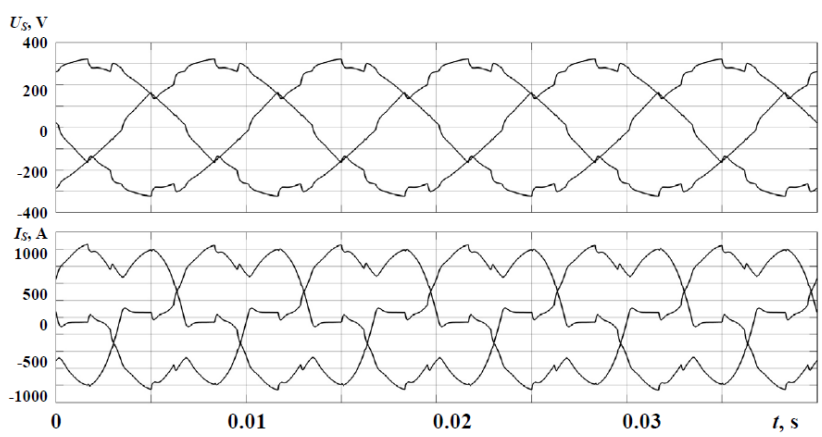

Fig. 7. Mains voltage and current in unregulated mode in conditions of external symmetrical distortions

Let us evaluate the quality of operation of the control systems under consideration, introducing additional asymmetry into the supply voltage.

Figures 9-11 show timing diagrams of the mains voltage and current for three operating modes of the VSAR CS under conditions of external asymmetric distortions of the power supply. 


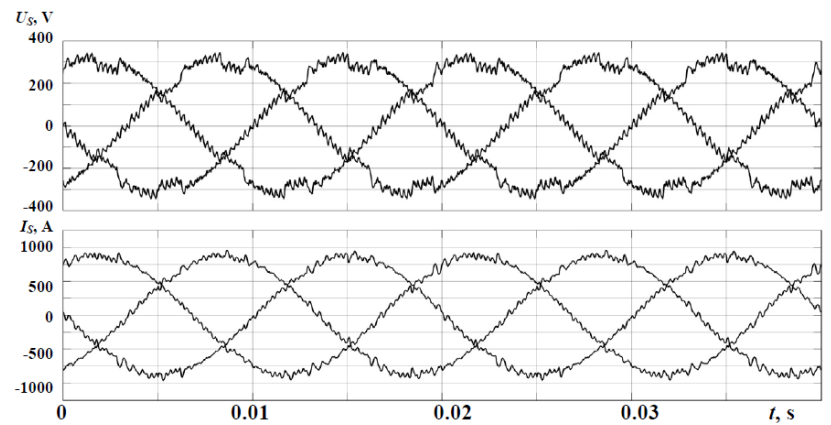

Fig. 8. Mains voltage and current with VSAR in conditions of external symmetric distortions

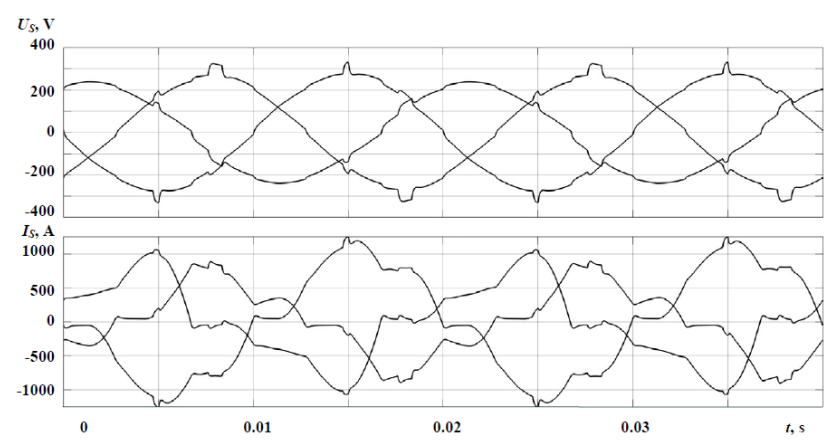

Fig. 9. Mains voltage and current in unregulated mode in deep unbalanced distortion conditions

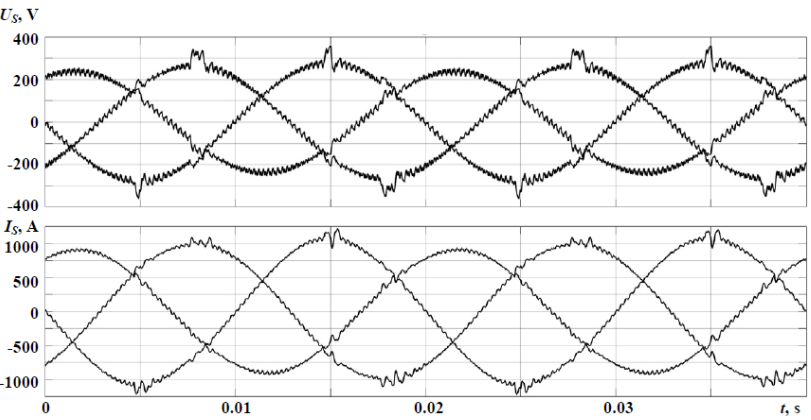

Fig. 10. Mains voltage and current with parametric CS in deep unbalanced distortion conditions

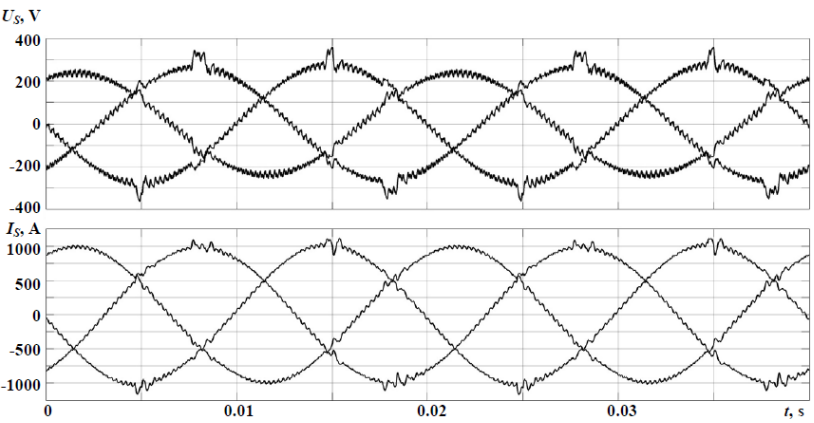

Fig. 11. Mains voltage and current with vector VSAR CS in deep unbalanced distortion conditions

Table 4 shows the indicators for assessing the quality of the mains with deep asymmetric distortions of the power supply voltage for three operating modes of the VSAR CS.

Analysis of the data obtained shows that with deep distortion of the mains parameters and VSAR operation in uncontrolled mode, the mains current and voltage differ significantly from the sinusoid, there is an asymmetry of currents and voltages in phases, $T H D_{I}$ and $T H D_{U}$ indicators are exceeded. When VSAR operates under such conditions, the vector CS is already significantly more efficient than the parametric one - it balances the currents consumed from the network much better.

Table 4

Mains parameters for three options of VSAR control system operation in conditions of deep network distortions

\begin{tabular}{|l|c|c|c|c|c|c|c|c|c|}
\hline $\begin{array}{c}\text { Circuit } \\
\text { type }\end{array}$ & \multicolumn{3}{|c|}{ Without VSAR } & \multicolumn{3}{c|}{ Parametric CS } & \multicolumn{3}{c|}{ Vector CS } \\
\hline $\begin{array}{l}\text { phase } \\
\text { parameter }\end{array}$ & $\mathrm{A}$ & $\mathrm{B}$ & $\mathrm{C}$ & $\mathrm{A}$ & $\mathrm{B}$ & $\mathrm{C}$ & $\mathrm{A}$ & $\mathrm{B}$ & $\mathrm{C}$ \\
\hline$I_{2}$ & 775,6 & 579,4 & 516,6 & 611,6 & 517,1 & 576,9 & 580,6 & 559,6 & 572,5 \\
\hline$U_{2}$ & 198,4 & 168,4 & 193,7 & 200,6 & 170,6 & 194,2 & 200,9 & 170,8 & 194 \\
\hline$T H D_{I}$ & 17,08 & 39,34 & 30,8 & 3,5 & 3,14 & 3,48 & 3,4 & 2,95 & 3,47 \\
\hline$T H D_{U}$ & 4,15 & 6,54 & 7,21 & 6,31 & 6,66 & 8,18 & 6,39 & 6,69 & 8,31 \\
\hline$K_{N S 2}$ & \multicolumn{3}{|c|}{9,85} & \multicolumn{6}{|c|}{9,5} \\
\hline
\end{tabular}

The $T H D_{I}$ and $T H D_{U}$ values during operation of the two types of CS are practically the same and comply with the standards [8]. None of the considered CS can improve the symmetry of the supply voltages.

\section{Conclusions.}

1. In the conditions of symmetric distortions of the supply voltage, the VSAR vector control system proposed by the authors has a slight advantage over the parametric one.

2. In the presence of unbalance in the voltage of the power source, VSAR with a vector control system consumes a current from the mains, the deviation of the effective value from the nominal value of which does not exceed $2 \%$ in each phase. The deviation of the effective value of the phase current from the nominal in the parametric system reaches $10 \%$ both up and down. That is, in the mode of deep voltage distortion of the supply mains, VSAR with a vector control system balances the current consumed from a three-phase network much better than with a parametric one.

3. VSAR has shown high efficiency in all modes of operation, demonstrating the values permissible by the standards for the total harmonic distortion of the current and voltage of the mains at the connection point. The studies carried out allow to say that the use of vector control systems, according to the authors, is the most promising, and their further research and optimization is an urgent task.

Conflict of interest. The authors declare that they have no conflicts of interest.

\section{REFERENCES}

1. Vaideeswaran V., Sankar N. Control Techniques of Three Phase PWM Rectifier. International Journal of Engineering and Advanced Technology, 2018, vol. 8, iss. 2S, pp. 148-152. Available at: https://www.ijeat.org/wpcontent/uploads/papers/v8i2s/B10391282S18.pdf (Accessed 10.10.2020).

2. Jamma M., Akherraz M., Barar M. ANFIS Based DC-Link Voltage Control of PWM Rectifier-Inverter System with Enhanced Dynamic Performance. IECON 2018 - 44th Annual Conference of the IEEE Industrial Electronics Society, Washington, DC, USA, 2018, pp. 2219-2224. doi: https://doi.org/10.1109/iecon.2018.8591620.

3. Premkumar K., Prema Kandasamy, Vishnu Priya M., Thamizhselvan T., Ron Carter S.B. Three-Phase Rectifier Control Techniques: A Comprehensive Literature Survey. 
International Journal of Scientific and Technology Research, January 2020, vol. 9, iss. 1, pp. 3183-3188. Available at: http://www.ijstr.org/final-print/jan2020/Three-phase-RectifierControl-Techniques-A-Comprehensive-Literature-Survey.pdf (Accessed 10.10.2020).

4. Trinh Q.N., Choo F.H., Tang Y., Wang P. Control Strategy to Compensate for Current and Voltage Measurement Errors in Three-Phase PWM Rectifiers. IEEE Transactions on Industry Applications, May 2019, vol. 55, no. 3, pp. 2879-2889. doi: https://doi.org/10.1109/tia.2019.2894107.

5. Zhou D., Li X., Tang Y. Multiple-Vector Model-Predictive Power Control of Three-Phase Four-Switch Rectifiers With Capacitor Voltage Balancing. IEEE Transactions on Power Electronics, Jul. 2018, vol. 33, no. 7, pp. 5824-5835. doi: https://doi.org/10.1109/tpel.2017.2750766.

6. Krylov D., Kholod O., Radohuz S. Active rectifier with different control system types. 2020 IEEE 4th International Conference on Intelligent Energy and Power Systems (IEPS), Istanbul, Turkey, 2020, pp. 273-278. doi: https://doi.org/10.1109/ieps51250.2020.9263226.

How to cite this article:

Krylov D.S., Kholod O.I. The efficiency of the active controlled rectifier operation in the mains voltage distortion mode. Electrical Engineering \& Electromechanics, 2021, no. 2, pp. 30-35. doi: 10.20998/2074-272X.2021.2.05.
7. Tlili F., Bacha F., Guesmi M. New switching lookup table for direct power control of a three-phase PWM rectifier. 2018 9th International Renewable Energy Congress (IREC), Hammamet, Tunisia, 2018, pp. 1-5. doi: https://doi.org/10.1109/irec.2018.8362513.

8. IEEE STD 519-2014. Recommended Practice and Requirements for Harmonic Control in Electric Power Systems. doi: https://doi.org/10.1109/IEEESTD.2014.6826459.

Received 10.11.2020

Accepted 29.12.2020

Published 05.04.2021

D.S. Krylov ${ }^{1}$, PhD, Associate Professor,

O.I. Kholod ${ }^{1}$, PhD,

${ }^{1}$ National Technical University «Kharkiv Polytechnic Institute», 2, Kyrpychova Str., Kharkiv, 61002, Ukraine,

e-mail: Denis.Krylov@khpi.edu.ua, Olha.Kholod@khpi.edu.ua 